TECHNICAL TRANSACTIONS 6/2017

CZASOPISMO TECHNICZNE 6/2017

CIVIL ENGINEERING

DOI: $10.4467 / 2353737$ XCT.17.093.6569

\author{
Agnieszka Leśniak (alesniak@izwbit.pk.edu.pl) \\ Grzegorz Piskorz \\ Faculty of Civil Engineering, Cracow University of Technology
}

\title{
POTENTIAL REASONS FOR WORKS DELAYS RESULTING \\ FROM THE PROVISIONS OF THE AGREEMENT
}

POTENCJALNE PRZYCZYNY OPÓŹNIEŃ ROBÓT BUDOWLANYCH

WYNIKAJĄCE Z POSTANOWIEŃ UMOWY

\begin{abstract}
The course of the construction process in time is shaped by a variety of factors, which, in effect, may become the reason for delays in project completion. The paper presents the outcome of research performed with Polish building works contractors. One of the aims was to try to identify the potential reasons for delays in construction works, which result from the provisions of the agreement. Early recognition and an assessment of possible risks may assist the contractor's attempts to eliminate them or to lessen the scale of delays in the project implementation.
\end{abstract}

Keywords: delays, construction works, factor identification

\section{Streszczenie}

Przebieg procesu budowlanego w czasie kształtowany jest przez wiele czynników, które w efekcie mogą stać się przyczyną nieterminowego ukończenia przedsięwzięcia. W artykule zaprezentowano wyniki badań przeprowadzonych wśród polskich wykonawców budowlanych. Jednym z zamierzeń była próba identyfikacji potencjalnych przyczyn opóźnień robót budowlanych wynikających z postanowień umowy. Wczesne rozpoznanie i ocena możliwych zagrożeń może wspomóc działania wykonawcy w celu ich eliminacji lub zmniejszenia skali opóźnień w realizacji przedsięwzięcia.

Słowa kluczowe: opóźnienia, roboty budowlane, identyfikacja czynników 


\section{Introduction}

Despite the advanced modern technology and many tools facilitating the management of the construction process, delay of the construction implementation remains common. Early identification and the subsequent limitation or even elimination or the potential reasons for such delays may contribute to the efficient and punctual project completion.

The study in [15] revealed that the prolongation of the project completion in Poland is typically caused by the extended duration of the procedures preparing a given project for implementation.

Exceeding the time limit of works implementation specified in the agreement is a common problem in the construction industry and is significant for both the investor and the contractor. The provisions of the agreement between the investor and the contractor decide which party is going to be responsible for delays. On these grounds, the way the risks related to the implementation of construction works are distributed between the parties is established.

The paper presents the results of research dealing with building contractors designed to identify and assess the significance of factors that may generate delays in construction works. The authors proposed a classification of factors, which they predicted to be likely to be identified as early as at the stage of procedures preceding signing of the contract and which result from the provisions of the agreement.

\section{Research into the reasons for construction works delay in Poland and abroad}

The analysis of Polish literature reveals that a lot of the research conducted so far concerned the identification of factors that generated delays in the completion of construction works. Paper [11] presents an overview of attempts to group the factors that have been identified in the foreign literature. Publication [12] depicts groups of factors and presents the results of a preliminary survey into the delay in construction works in the opinion of various participants of the investment process. The authors of [7] focused solely on the investors' opinions. According to this group of participants, the most important reasons for the delay in construction works are the following: mistakes in project documentation, low quality of the work force and adverse weather conditions. Publications $[2,8]$ and $[10]$ involve attempts made by various researchers to identify the factors influencing works delays in the opinion of contractors. Works [10] and [2] prove that, according to contractors, the most significant factors that generate delays include mistakes in project documentation, the investor's slow decision-making process and a low quality of management and supervision of the construction site. However, according to another research published in [2], the most vital factors include a large number of mistakes in project documentation, poor cooperation between the investor (the orderer) and the contractor and adverse weather conditions. Paper [8] analysed the results of research into the time risk factors presented in foreign literature, which were then compared with the results of surveys conducted among contractors in Poland. Some of the 
publications also present the possibilities of applying various methods to analyse delaycausing factors: using the Dematel method [5], factor analysis [7], or the introduction of flexible strategies [14].

These works represent the increase of the interest in the problem of delays in construction works in Poland and the reasons for their occurrence. The majority concerns the identification and classification of delay-causing factors. Yet it is the possibility to predict delays that remains a vital issue for contractors and investors [1]. In publications [16, 17], the author attempted to develop a method that could predict adverse events, which could occur during the implementation of a project, either indirectly (through time delays in activities performed) or directly on the cost of the investment and the execution time.

A detailed foreign literature review is presented in [7]. It reveals that, so far, more than 100 factors influencing delays have been identified abroad, and researchers classified them in a variety of ways. One of the first studies was conducted as early as in the 70s in the USA [4]. One group of seventeen factors was established, including such elements as: weather conditions, work force availability and subcontractors' contribution. The most detailed division of factors was proposed in [13], in which ten categories were presented. Other interesting instances of categorization of factors can be found in [6] and [9].

Both the Polish and foreign publications concerning construction works delays prove that the problem is common [7]. The risk of delays during building works is high, yet the authors of the present article would like to prove that some of the factors could be identified right at the project planning stage.

\section{Factors causing delays resulting from the provisions of the agreement}

\subsection{Methodology}

The aim of this research was to show the reasons for delays in construction works according to building contractors, resulting from the provisions of the agreement. The research was performed at the beginning of 2017. Using a modern Internet platform Profitest. $p l$ that allows to prepare online surveys, a questionnaire was prepared. The relevant link was sent to 462 building contractors from all over Poland. 97 correctly completed questionnaires were received back, which is $21 \%$ of the total number sent out.

The questionnaire consisted of two parts. The first one included 3 questions concerning the professional experience of the participant, the number of people employed in the company and the operating range of the business. The greatest number of the respondents (31\%) were engineers with over 20-year experience. More than a half (52\%) represented large companies employing over 250 people. The operating range of the respondents' businesses included both the domestic market (44\%) and the international market (46\%).

The second part of the questionnaire contained 20 factors found in the provisions of the agreement that can cause delays in construction works. They were arbitrarily assigned by the authors of the present paper to 6 groups, namely: 1 - Project Documentation, 
2 - Administrative Decisions, 3 - Changes in Law, 4 - Construction Site, 5 - Works Planned in Winter, 6 - Social Conditions.

The respondents assessed the value of each factor by choosing a relevant number on a five-point scale: 1 - unimportant; 2 - of little importance; 3 - of average importance; 4 - important; 5 - very important. Then, for each factor, an average evaluation was calculated.

\subsection{The analysis of the results in each group of factors}

\subsubsection{Group 1 - Project Documentation}

For the contractor, project documentation is essential. It decides on the scope of the planned works and becomes the basis for the agreement. It is one of the elements that influence the shape of the tender. This group includes the following factors: 1 - lack of a complete building permit design or a detailed design; 2 - lack of a complete geology report; 3 - lack of a complete stocktaking or identification of underground networks; 4 - lack of a complete description of the order (too general, suggesting many solutions).

In the ranking created on the basis of the average assessment of the importance of the given factors, the highest evaluation was granted to the factor: lack of a complete building permit design or a detailed design (Fig. 1). Still, the difference from the remaining factors is very small. The evaluations of all the factors in this group are about 4; therefore, it can be concluded that all the factors in this group are important.

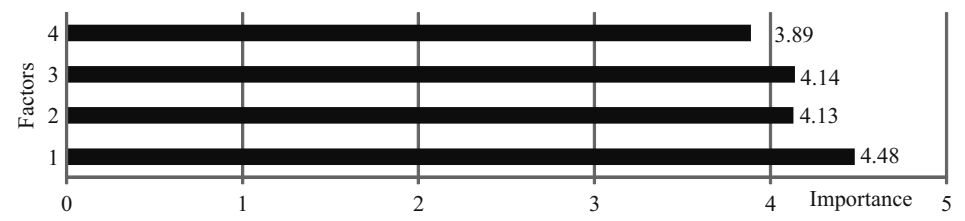

Fig. 1. Reasons for delay in the group: Project Documentation - ranked by importance (Source: own study)

In addition, the respondents proposed other factors, ones that the authors had not included in the questionnaire. These included: mistakes in project documentation, lack of reliable inter branch coordination, inconsistencies in the building permit design, the detailed design and in the technical specification.

\subsubsection{Group 2 - Administrative Decisions}

Before the investment receives the final building permit or the decision on permission for the implementation of a road project, it is necessary to obtain many agreements and permits, hence the next group proposed is Administrative Decisions with the following factors: 1 - not issuing within the statutory period the appropriate decision of, for example, building permit or permission for the implementation of a road project; 2 - mistakes in permits or in decisions 
required for the implementation of the subject of the order; 3 - the expiry of the agreement validity, such as the permit required by Water Law Act; 4 - the risk of delays related to the limitations resulting from the provisions of the administrative decisions which the ordering party did not include in the terms of reference, such as logging and removing habitats.

In the ranking created on the basis of the average assessment of the importance of the given factors, the highest evaluation was granted to the factor: not issuing the appropriate decision within the statutory period. The remaining factors, as the ones described above, received approximately 4 points, which should be unambiguously interpreted that they are all important (Fig. 2).

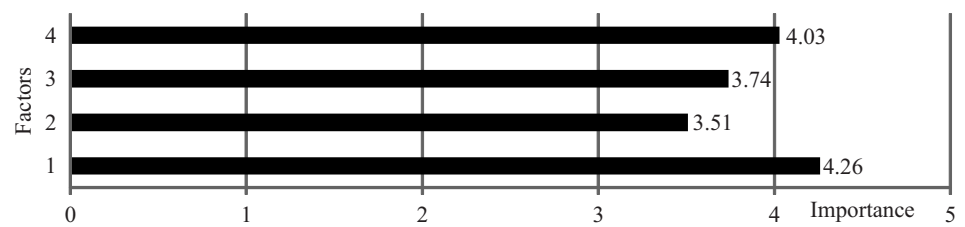

Fig. 2. Reasons for delay in the group: Administrative Decisions - ranked by importance (Source: own study)

Moreover, the respondents in this group also pointed to such additional factors as: other administrative requirements, for example, heritage conservator supervision and archaeological supervision, disregarding other necessary administrative permits by the ordering party, for instance, arrangements with local road authorities about determining the routes of trucks.

\subsubsection{Group 3 - Changes in Law}

The project must comply with the regulations in force at the time of the ordering party's construction works acceptance. References in the contract to the published standards are regarded as references to the issue of the current contract on the date of the tender submission, unless the contract states otherwise. In the case of the new or revised national standards coming into force after the date of tender submission (that is, during the contract implementation), the ordering party makes a decision about ensuring compliance with such standards. [3]. Therefore, a group Changes in Law has been proposed, including such factors as: 1 - changes in the regulations in the Act on Nature Conservation [22] and Water Law [21], for example, on the basis on the agreement on nature conservation, within the landscape protection area, prohibition of earthworks that permanently deform the terrain may be introduced; 2 - changes in the regulations in the Energy Law [19] specifying, among others, the rules of concluding contracts for connection to the network, or requirements for installations and networks submitted for connection, such as building connection; 3 - changes in the regulations in the Geodetic and Cartographic Law [18], which, among others, regulates the register of geodetic network utilities, especially important at the stages of investment planning; 4 - changes in the regulations in the Geological And Mining Law [23] related to, for instance, performing geological works and preparing geological and engineering 
documentation necessary to construct a building object when a geology engineering report is not sufficient; 5 - changes in the regulations in the Environmental Law [20], for example, if nature protection is not possible, but the Law requires that actions must be undertaken to repair the damage, especially by environmental compensation.

The average evaluation of the factors in this group is about 3 , which means that the respondents consider the problem related to changes in law as of average importance (Fig. 3). The respondents added the following factors: changes in the project due to the imprecise provisions in the permission for the implementation of a road project and changes in the tax legislation.

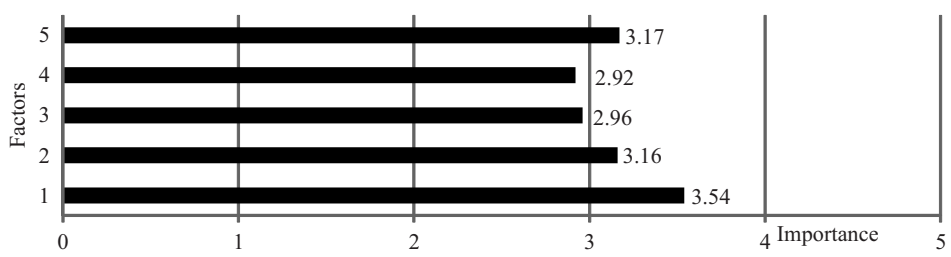

Fig. 3. Reasons for delay in the group: Changes in Law - ranked by importance (Source: own study)

\subsubsection{Group 4 - Construction Site}

A vital stage for the timely start of the project is transferring the building site within the contractually prescribed period. Failure to transfer it for reasons attributable to the ordering party or other, beyond the contractor's control, generates delays. Therefore, a group called the Construction Site was proposed, consisting of the following factors: 1 - having no right to administer the area for construction purposes on the part of the investor; 2 - lack of possibility to begin works due to the presence of places of worship at the construction site, for example, shrines; 3 - lack of access to part of the site due to undocumented environmental conditions or unregulated development areas.

The answers provided by the respondents reveal that having no right to administer the area, whole or a part of it, for construction purposes on the part of the investor is the highestranking factor that may cause delays (Fig. 4).

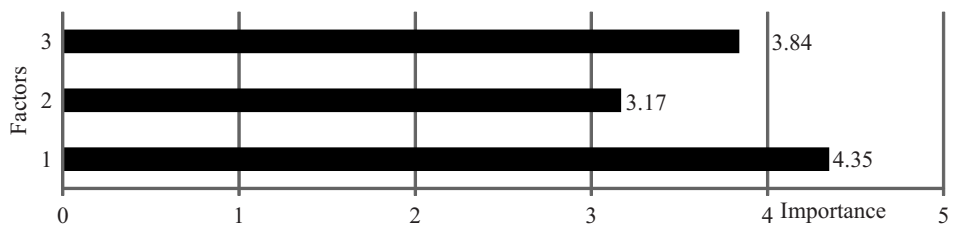

Fig. 4. Reasons for delay in the group: Construction Site - ranked by importance (Source: own study) 


\subsubsection{Group 5 - Works Planned in Winter}

Planning construction works in winter requires taking into consideration adverse weather conditions that could influence the time of completion the subject of the order. This is the only group that consists of only one factor. Here, the respondents did not propose any other factors, yet they did pay attention to the reasons for such works planning by the ordering party. This factor received an average evaluation of 3.89, which means that it is important as a potential reason for delays.

\subsubsection{Group 6 - Social Conditioning}

Protests of residents or blocking entrance to the construction site by various organizations have a significant influence on the occurrence of delays in construction works. Therefore, the authors proposed a group with three basic factors: 1 - the possibility of constraints and difficulties in accessing the building site; 2 - possible protests of residents living in the area neighbouring the construction site; 3 - possible protests related to environmental protection.

The average evaluations of the factors in this group range between 3 to 4 points, therefore the problem of social conditioning was judged as important (Fig. 5).

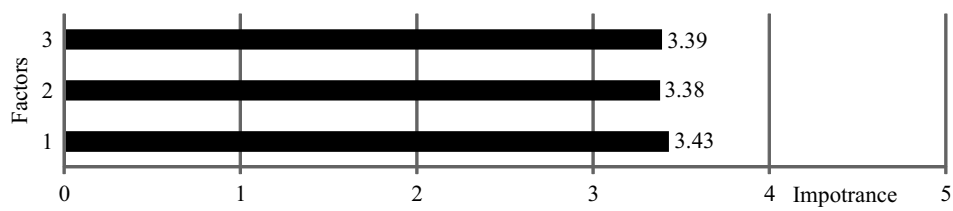

Fig. 5. Reasons for delay in the group: Social Conditioning - ranked by importance (Source: own study)

\section{Conclusions}

The present study involves a classification of factors that can cause delays of construction works into 6 groups. The factors proposed include only those that the authors judged as possible to identify before concluding the contract and which result from the provisions of the agreement. In total, 20 factors were indicated.

The analysis of the research results revealed that 3 groups out of 6, namely Project Documentation, Administrative Decisions and Construction Site, contain factors ranked above 4 points. The most important factors causing delays of construction works include the lack of a complete building permit design or a detailed design, not issuing the appropriate decision within the statutory period and having no right to administer the area for construction purposes on the part of the investor.

What is worth emphasizing is the strong commitment of the participants, who frequently added new factors to those proposed by the authors. Some of the additions the authors are planning to analyse further in the future research. 
The results obtained show that, as early as at the planning stage, the analysis of the provisions of the agreement reveals a number of factors which can cause delays during the performance of the works. Their identification, evaluation and appropriate actions undertaken to limit or even eliminate the factors may decrease the scale of delays in construction projects.

\section{References}

[1] Anysz H., Analiza zależności opóźnień w realizacji kontraktów na wykonanie robót budowlanych od czynników leżących poza sfera organizacji budowy i robót budowlanych, Teoretyczne podstawy budownictwa, T. II, Procesy budowlane, 2012, 69-82.

[2] Anysz H., Zbiciak A., Przyczyny powstawania opóźnień w realizacji kontraktów budowlanych - analiza wstępnych wyników badania ankietowego, Autobusy: Technika, Eksploatacja, Systemy Transportowe, (3), 2013, 963-972.

[3] Akram S. et al., Opóźnienia i zakłócenia w projektach budowlanych, Komisja Europejska, Leonardo da Vinci - Transfer Innowacji, Warszawa, Ankara, Ascot, Mondavio 2012.

[4] Baldwin J.R., Manthei J.M., Causes of delays in the construction industry, ASCE Journal of the Construction Division, 97, 1971, 177-187.

[5] Dytczak M., Ginda G., Wojtkiewicz T., Identyfikacja roli czynników opóźnień realizacji złożonych przedsięwzięć budowlanych, Budownictwo i Inżynieria Środowiska, 2, 2011, 481-485.

[6] Faridi A.S., El-Sayegh S.M., Significant factors causing delay in the UAE construction industry, Construction Management and Economics, Vol. 24, Issue 11, 2006, 1167-1176.

[7] Głuszak M., Leśniak A., Czynniki powodujące opóźnienia budowy - wielowymiarowa analiza statystyczna, [In:] Zastosowanie metod matematycznych w wybranych problemach zarzadzania w budownictwie, S. Belniek (ed.), Kraków 2015, 79-105.

[8] Jaśkowski P., Biruk S., Analiza czynników ryzyka czasu realizacji przedsięwzięć budowlanych, Czasopismo Techniczne, 1-B/2010, 2, 2010, 157-166.

[9] Kazaz A., Ulubeyli S., Tuncbilekli N.A., Causes of delays in construction projects in Turkey, Journal of Civil Engineering and Management, 3/2012, 426-435.

[10] LeśniakA.,Przyczynyopóźnieńbudowyw opiniach wykonawców, Czasopismo Techniczne, 1-B/2012, 2, 57-68.

[11] Leśniak A., Skąd się biorą opóźnienia?, Builder, 1/2010, 24-25.

[12] Leśniak A., Plebankiewicz E., Opóźnienia w robotach budowlanych, Zeszyty naukowe WSOWL, Nr 3 (157) 2010, 332-339.

[13] Ogunlana S., Promkuntong K., Construction delays in a fast-growing economy: comparing Thailand with other economics, International Journal of Project Management, 14 (1), 1996, 37-45.

[14] Pasławski J., Drzewiecka J., Analiza zakłóceń procesów budowlanych, Budownictwo i Inżynieria Środowiska, 2/2011, 475-479.

[15] Połoński M., Wiarygodność szacowanych kosztów planowanych inwestycji na tle barier $w$ procesie inwestycyjnym. Acta Scientiarum Polonorum. Architectura 2007, 6 (3), 35-41. 
[16] Skorupka D., Identification and Initial Risk Assessment of Construction Projects in Poland, Journal of Management In Engineering", Vol. 24, No. 3, American Society of Civil Engineers, 2008, 120-127.

[17] Skorupka D. The method identification and qualification of construction project risk, Archives of Civil Engineering, LI, 4, Warszawa 2005, 647-662.

[18] Ustawa z dnia 17 maja 1989 r. Prawo geodezyjne i kartograficzne, Dz. U. 1989 nr 30, poz. 163.

[19] Ustawa z dnia 10 kwietnia 1997 r. Prawo energetyczne, Dz. U. 1997 nr 54, poz. 348.

[20] Ustawa z dnia 27 kwietnia 2001 r. Prawo ochrony środowiska, Dz. U. $2001 \mathrm{nr} 62$, poz. 627.

[21] Ustawa z dnia 18 lipca 2001 r. Prawo wodne, Dz. U. 2001 nr 115, poz. 1229.

[22] Ustawa z dnia 16 kwietnia 2004 r. O ochronie przyrody, Dz. U. 2004 nr 92, poz. 880.

[23] Ustawa z dnia 9 czerwca 2011r. Prawo geologiczne i górnicze, Dz. U. 2001 nr 163, poz. 981. 